\title{
Financial instruments disclosure: Do audit committee and audit quality matter?
}

\author{
Adamu Garba Zango \\ Department of Accounting \& Finance, Baze University, Abuja-Nigeria \\ *Corresponding Author email: zangoage@gmail.com \\ Submission: 24 December 2020 \\ Revised: 26 March 2021 \\ Accepted: 18 April 2021
}

\begin{abstract}
This study was motivated by a dearth of empirical literature on the relationship between audit committee characteristics, audit quality and financial instruments disclosure of a developing country. From the Nigerian Stock Exchange, up to date records over the period of three years (that is, from 2016 to 2018) were sourced from the sample size of all the 20 commercial banks and selected 30 insurance companies. After considering the dual role of audit committee as monitors to shareholders wealth and advisors for transparent managerial action based on quality audit information, the empirical analysis which employs a generalised method of moment estimator (GMM) that account for endogeneity concerns (simultaneity, reverse causality and unobserved heterogeneity)indicate that, audit committee meeting frequency $(\log \mathrm{acm})$ and audit quality positively and significantly relates to financial instruments disclosure each at $5 \%$ level. This result indicates the incentivizing role of audit on the new regulation as it applies to financial institutions in Nigeria. Moreover, firm size (log fsize) is positively related to financial instruments disclosure at $5 \%$ level of significance. On the contrary, this study found no significant relationship existing amongst audit committee size and financial instruments disclosure and audit committee meeting frequency and financial instruments disclosure of financial institutions in Nigeria. The study's implications in the Nigerian context have been discussed.
\end{abstract}

Keywords: Financial Instruments, Disclosure, Audit Committee, Audit Quality

JEL Classification: C2O, G23, M42

\section{INTRODUCTION}

Good corporate governance entails shareholder value through an agent by positively turning around corporate affairs aimed at ensuring the collective interest of all stakeholders (Gill, Biger, Mand \& Shah, 2012). Today's investors and other stakeholders demand nothing less than transparency and accountability which is only possible with sound corporate governance. Therefore, effective board committees and management strategic financing choices in form of audit quality are only possible with quality corporate governance practices at audit committee and management level. Consequently, corporate governance variables such as audit committee size, audit committee expertise and audit committee meeting frequency may have a desirable impact on the financial instruments' disclosure decisions of banks and insurance companies in emerging capital markets.

The choice of banks and insurance companies is informed by the fact that although these institutions configure their board committees according to the best practice principles of their non-financial counterpart, financial management literature showed that it may 
display different effect on audit committee characteristics with those of non-financial firms (Andres et al., 2012; Andres \& Vallelado, 2008). Hence, studying a modest framework without segregating entities into either financial or non-financial firms may not be an optimal decision. This study is therefore set to be one of the pioneers in that respect.

The underpinning classical theory that relates to corporate governance is the agency theory postulation (Berle \& Means, 1932; James, 1933). This concept according to Jensen and Meckling (1976) explains the corporate governance issues associated with ownership being divorced from the control of the firm. In this kind of relationship, the proprietor-manager relations theorizes that companies consist of two parties; the management (agent) and the owners (principals). Based on this association, the principal relinquishes authority with respect to the utilization of company's resources to the agent upon some form of compensation based on written agreements. However, since the objectives of principals and agents may not align as a result of conflicting interests, the owner may need to constantly evaluate the agent's performance through such institutions as for example audit committee or professional auditor (Kajananthan, 2012).

With business expansion due to globalisation, shareholders are now categorised into block holders with controlling interest in the business and small investors who are termed the minorities. Modern accounting theories view the conflict between controlling shareholders and minority investors to be the main source of apprehension in corporate governance. Hence, scholars view this concern as the major determinant of a company's capital structure decision (Gill et al., 2012). Yet empirical evidence to date is still sketchy on clear relations between corporate governance attributes, audit quality and financial instruments disclosure of financial institutions in emerging capital markets. This is an important omission in the search for knowledge in financial management study which this paper seeks to explore.

Furthermore, a review of corporate governance literature reveals that there was not enough empirical evidence on corporate governance characteristics and audit quality with an intertwined relationship between the two variables through agency costs. For example, few studies focus on the impact of corporate governance and firm performance (Ibrahim \& Danjuma, 2020; Ogunsanwo, 2019; Saha \& Kabra, 2019; Balagobei, 2018). Moreover, fewer others discuss corporate governance and capital structure in developed economies (Zaid, Wang, Sara, Issa, Saleh, \& Ali, 2020; Vijayakumaran, \& Vijayakumaran, 2019; Gill et al, 2012; Abor, 2007). However, almost all these studies are concentrated on non-financial sectors of developed economies. This is particularly worrisome as the financial sector and especially the banking and insurance industry of promising emerging markets such as Nigeria is completely neglected (Barako et al., 2006; Abiola \& Ojo, 2012).

This study synthesis the various literatures and examines the impact of corporate governance and audit quality on financial instruments disclosure of listed financial institutions in Nigeria. The impact of three corporate governance independent variables such as audit committee size, audit committee expertise and audit committee meeting frequency on financial instruments disclosures are examined. The control variable in this study is the firm size which prior studies found positively relating with the dependent 
variable of this study. The dependent variable of the study as earlier stated is financial instruments disclosure represented by IFRS7 disclosure required items. Finally, this study contributes to the going demand for good corporate governance literature on risk disclosure in developing economies because previous risk studies mainly focus on the US and other developed country's setting, in which risk reporting is heavily regulated (Hope et al., 2016 \& Thai \& Birt, 2019) with very scanty proof on developing economies (Elshandidy, Shrives, Bamber \& Abraham, 2018).

\section{LITERATURE REVIEW}

\subsection{DEPENDENT VARIABLE}

International Financial Reporting Standard7 (IFRS7) is an accounting framework that was first issued by the International Accounting Standards Committee (IASC) in August 2005. However, these rule-based standards became effective on 1st January 2007 following the reform of the financial crisis of 2007/8 and the need for re-evaluation regarding financial instruments disclosure. Prior research evaluated the degree of compliance using mandated statutory obligations of IAS/IFRS7 (Glaum \& Street, 2003; Street \& Gray, 2002; Street \& Bryant, 2000; Hodgdon et al. 2008). According to Hodgdon et al. (2008), the commonly used technique is the dichotomous or Cooke's approach. As per Cooke (1989; 1992), the technique allows significant results to each disclosure item. This according to researchers reduces subjectivity and biasness in reporting (Owusu-Ansah \& Yeoh, 2005; Owusu-Ansah, 1998). A known data is graded "7" and the unknown is graded "O". It is typically called the dichotomous approach and is described using the formula given below:

$$
C S_{J}=\frac{T \sum_{i=1}^{m} d i}{M=\sum_{i=1}^{n} d i}
$$

In the formula above,

CS I represents the total compliance score for each company in which $0 \leq \mathrm{CSj} \leq 1$

$T$ represents the total number of items disclosed $\left(d_{i}\right)$

$\mathrm{J}$ stands as a proxy for the name of the company under consideration

$\mathrm{M} \leq \mathrm{n}$; where $\mathrm{m}$ is the total number of applicable items the company $\mathrm{j}$ is to disclose

\subsection{INDEPENDENT VARIABLES}

\subsubsection{Audit Quality}

Prior empirical studies observed that International audit firms give quality reports to the stakeholders through the board of directors (Abozaid, Elshaabany \& Diab, 2020; Ado, Rashid, Mustapha \& Ademola, 2020; Albitar, Gerged, Kikhia \& Hussainey, 2020; Sattar, Javeed, \& Latief, 2020; Wakil, Alifiah, Teru, 2020 and Chersan, 2019). Ado, Rashid, Mustapha and Ademola (2020) observed that the report as submitted by auditors significantly influences the quality of financial instruments information disclosure in an annual report. 
Although professional auditors such as the big 4 audit firms charge higher audit fees, they none the less have more skills and expertise for detecting fraud and irregularities (Abozaid, Elshaabany \& Diab, 2020). Hence, they are in a better position to ensure adequate information disclosure by their clients than smaller audit firms. Studies by Phan, Lai, Le and Tran (2020); Mustafa and Muhammad (2018) of Nigerian listed oil and gas companies; Hanoi stock exchange; Eshitemi and Omwenga (2017) from Nairobi stock exchange; Farouk and Hassan (2014) from the Nigerian stock exchange; Jusoh, Ahmad and Omar, (2013) in a study of Malaysian listed firms and Bouaziz (2012) from the Tunisian parastatals all found that firms audited by big 4 audit firms have a positive and significant influence on disclosure that leads to enhanced firm performance.

In contrast, other studies revealed a significantly negative relationship between auditor size and firm performance based on disclosure. These studies include Elewa and El-Hadded (2019) in a study of Egyptian companies; Aledwan, Yaseen and Alkubisi (2015) in Jordanian cement companies. Moreover, Monametsi and Agasha (2020) found that audit quality is a negative but non-significant predictor of firm performance that is due to disclosure in the sub-Saharan African countries studied.

Following the above discussion, it is proposed that:

H1: There is a significant relationship between audit quality proxy by audit firm size and IFRS7 disclosure.

\subsubsection{Board Committees}

A previous study by Vafeas (1999) saw that the board discharges its duties by making use of standing committees. Audit, risk management, governance and remuneration which is a representation of the presence of specialized standing sub-committees signifies higher diligence on the part of board directors. This study concentrates on audit committee characteristics because it is a statutory requirement in Nigeria is regulated by the Companies and Allied matters Act (CAMA, 1960). Secondly, this study document audit quality given that audit was reported to be seriously compromised due to connivance between management and external auditors to defraud shareholders (Favere-Marchesi, 2000).

\subsubsection{Audit Committee Size}

In management monitoring and inspection, a large-sized committee commits more time and effort, whereas small committees put in less time and effort (Monks \& Minow, 2011). Andres et al., (2012) observe that boards of financial enterprises are distinct from the boards of non-financial corporations. Specifically, boards of banks and insurance companies seem to be larger and more independent than in the non-financial sectors. Xie et al. (2003) stated that with larger boards earnings management is unlikely. Likewise, the inability to detect earnings manipulation is confirmed to be one of the defects of small boards (Yu, 2008). This impliedly means that small boards have no cohesive ability which can lead to their manipulation by management or domination by block holders. 
Some previous research discovered that size and disclosure have significant positive relationships in the financial statements of banks (Abdul Rahman \& Ali 2006; Allini, Ferri, Maffei \& Zampella, 2020; Kao \& Chen, 2004). On the contrary, therefore, Earnings Management had a negative relationship with size (Xie et al. (2003). Other studies also discovered size to be a major preference of block investors due to the desire for informational advantage through their board committee representatives (Gompers and Metric, 2001; Falkenstein, 1996; Dahlquist and Robertson, 2001). From the above review, the study is hypothesized.

$\mathrm{H1}$ : There is a significant relationship between audit committee size and IFRS 7 disclosure.

\subsubsection{Audit Committee Expertise}

The Theory of Dependency argues that, according to (Daily et al., 2003), directors are essential advice source to CEOs which aim to increase a company's' value through disclosure in financial statements. Xie et al. (2003) are of the opinion that in disclosing manipulation in earning independent directors with corporate financial expertise are of uttermost importance. According to Bedard et al. (2004), the involvement of financial experts in the audit committee has also been found to have a negative effect on the possibility of disruptive income management. Positive market reaction on the appointment of experts in audit committee owing to their ability of earnings predictive disclosure was found by Karamanou and Vafeas (2005). It can be augured in regard to the discussion that a potential relationship exists between disclosure and audit committee financial expertise. Thus, we propose the hypothesis listed below:

H3: There is a very notable association between audit committee expertise and IFRS 7 disclosure

\subsubsection{Meetings of Audit Committee}

Meeting frequently is an indicator that the audit committee is very effective. Shareholders and other users of financial statements comprehend infrequent meetings as an indicator of lack of commitment and devotion in overseeing the financial reporting and audit processes, Xie et al. (2003). It is also observed that the frequency of meeting is allied with great reduction levels of earning management. It was argued that regular meetings significantly improve the transparency and sincerity of reported earnings hence improved earnings quality level, Bryan et al. (2004).

In order to ascertain the efficiency of financial reporting, Zhang et al. (2007) used the meeting frequency. Takiah \& Ruzaidah (2004) were of the view that the directors of successful financial reporting firms or businesses should meet more regularly. On the other hand, Vafeas (2005) noted that the relationship existing between the frequency of meeting and disclosure was negative. There were also no positive ties between frequency and consistency of financial reporting between Bedard et al. (2004) and Lin et al. (2006). On the basis of this review, we presumed that:

H4: There is a significant correlation between audit committee meeting frequency and IFRS 7 disclosure. 


\section{RESEARCH METHODS}

The hypothesis of this study is examined based on a sample of 50 listed companies made up of 20 commercial banks and 30 insurance companies of a developing country setting during the period from 2016 to 2018. This balanced panel data represents $87.00 \%$ of the total number of financial institutions (banks and insurance) with about $90 \%$ of bank assets and share capital of the studied country-Nigeria. The board of directors' data needed to build the panel was sourced from the Nigerian Stock Exchange database. The study obtains corporate governance information on audit committee characteristics from banks' annual reports sourced from the financial institution's respective web sites. Finally, this research uses Thomson Reuters and Bank Scope to obtain full data about company characteristics.

\subsection{ECONOMETRIC MODEL}

The empirical model for the dependent variable-financial instruments disclosure is denoted by IFRS7. The independent variables are clarified by the size of the audit committee (ACSIZE), the competence of the audit committee and the frequency of audit meetings (ACMET), while the "big4" represents the audit quality (AUDQ). The control variable which is firm size (FSIZE) was chosen based on theoretical and textual analysis (Lin et al., 2006).

The sample of this study includes cross-sectional and time-series (2016 to 2018) data from banks and insurance companies. In order to properly analyze this kind of sample, Analysis of panel data is the most effective technique because scholars are able to consider the unobservable and constant heterogeneity of each bank. Moreover, panel data is an econometric model that can deal with endogeneity as well as unobservable fixed effects of each entity in this case the banks and insurance companies.

This study also overcomes econometric challenges by using generalised method of moment's estimator (GMM). The GMM methodology permit scholars to potentially develop mechanisms for the variables which are helpful in econometric modeling. This study employs the two-step modified estimation standard errors for possible heteroskedasticity as suggested by Blundell \& Bond (1998) and Arellano \& Bover (1995). In addition, the econometric model reflects on the unobserved effect that converts variables into first differences and uses GMM to resolve endogeneity issues. The regression model for the study is analytically represented as follows:

IFRS7 $=\beta O+\beta_{1} A C S I Z E_{i t}+\beta_{2} A C E X P_{i t}+\beta_{3} A C M E T_{i t}+\beta_{4} A U D Q_{i t}+\beta_{5} F_{S I Z E_{i t}}+\varepsilon_{i t}$

Where:

ACSIZE= Audit committee size measured by audit committee members on board

ACMET= Audit committee meeting frequency measured by the number of meetings per annum

ACEXP = Audit committee expertise measured by the proportion of accounting experts in the committee 
$A \cup D Q=$ Audit quality represented by big4 measured as a dummy variable "1" if big4 and "O" otherwise

FSIZE = Firm size measured by the natural logarithm of total assets

\section{FINDINGS AND DISCUSSION}

\subsection{DesCRIPTIVE STATISTICS}

Table 1 presents the descriptive analysis of the dependent and independent variables employed in this study. From the table, it shows that the mean number of IFRS is 67.47 with standard deviation of 23.50, Skewness of 0.62 and Kurtosis of 2.08. The independent variables revealed that the mean of Audit Committee Size (ACS) is 1.75 with standard deviation of 0.11, negative Skewness of -1.80 and Kurtosis of 7.51. Audit committee expertise has a negative mean of 1.65 , standard deviation of 0.24 , Skewness of 1.46 and Kurtosis of 3.80 .

The audit committee meeting frequency has a mean of 1.05, standard deviation of 0.20 , Skewness of 0.91 and Kurtosis Of 7.58. Moreover, big4 audit firms have a mean of 0.55 , standard deviation of 0.49 , a negative Skewness of 0.22 and kurtosis of 1.05. The firm size has a mean of 2.86 with standard deviation of 0.13, Skewness of 0.66 and Kurtosis of 1.91. These figures are in line with findings by several researchers who argue in favor of range between 3 and 10 for Skewness and Kurtosis respectively (West et al., 1995; Curran et al., 1996; Kline, 2011).

Table 1. Descriptive Statistics of Variables

\begin{tabular}{lllll}
\hline Variables & Mean & Std. Dev. & Skewness & Kurtosis \\
Ifrs & 67.47 & 23.50 & 0.62 & 2.08 \\
I acs & 1.75 & 0.11 & -1.80 & 7.51 \\
Lace2 & -1.65 & 0.24 & 1.46 & 3.80 \\
Acm2 & 1.05 & 0.20 & 0.91 & 7.58 \\
Big 4 & 0.55 & 0.49 & -0.22 & 1.05 \\
Ifsize & 2.86 & 0.13 & 0.66 & 1.91 \\
\hline
\end{tabular}

\subsection{CORRELATIONS ANALYSIS}

Below in Table 2 shows the correlation analysis of the financial institutions governance variables. The figures advance some initial guesses about the determinants of audit committee characteristics, audit quality and financial instruments disclosure. For instance, there is a high positive correlation between IFRS and big4 audit firm (0.500), IFRS and audit committee size (0.300), IFRS and audit committee expertise (0.400). These variables indicate that have a significant impact on financial instruments disclosure of financial institutions in Nigeria. In line with Bryman \& Cramer (1997) this study's highest correlation coefficient between independent variables is 0.54 which is far less than 7 . Hence, multicollinearity is not of concern in the multivariate analysis. 
Table 2. Correlation Analysis

\begin{tabular}{lllllll}
\hline & Ifrs & acs & lace2 & lacm2 & Big4 & Ifsize \\
ifrs & 1.000 & & & & & \\
acs & 0.300 & 1.000 & & & & \\
lace2 & 0.400 & -0.261 & 1.000 & & & \\
lacm2 & 0.198 & 0.104 & 0.120 & 1.000 & & \\
Big4 & 0.500 & 0.164 & 0.169 & 0.085 & 1.000 & \\
Ifsize & 0.900 & 0.250 & 0.374 & 0.149 & 0.540 & 1.000 \\
\hline
\end{tabular}

\subsection{EMPIRICAL RESULTS}

Table 3 below reports the result of regression analysis using the generalised method of moment (GMM) estimation (Hallak, 2013). From the empirical analysis in the table, a percentage increase in audit committee expertise leads to a corresponding increase in financial instruments disclosure by 0.02591 consistent with findings in previous studies (Haque, 1994). Waresul Karim \& Ahmed (2005) found financial statements certified by the big 4 as more credible and are able to influence the production of an early annual report.

Similarly, a percentage decrease in audit committee meeting frequency leads to a corresponding decrease in financial instruments disclosure by 0.01009 although the result is found to be statistically insignificant. Moreover, a percentage increase in audit quality results in an increase in financial instruments disclosure of Nigerian financial institutions by 0.14056 . Furthermore, an increase in firm size by one percentage point results in a corresponding increase in financial instruments disclosure of listed Nigerian financial institutions by 0.93843 .

In summary, the result of this study indicates that audit committee accounting/ financial expertise and audit quality are important indicators of financial instruments disclosure in listed Nigerian financial institutions. Investors may therefore decide to hold other factors constant and use audit committee expertise and audit quality in predicting financial instruments risk disclosure of their financial institutions in which they have investments or they intend to invest.

Table 3. Multiple Regressions

\begin{tabular}{lllll}
\hline IFRS & Coeff. & Std. Dev. & $\mathbf{Z}$ & $\mathbf{P}>\mathbf{Z}$ \\
Ifrs I & 0.940 & 0.115 & 8.19 & 0.00 \\
acs & 0.761 & 1.680 & 0.45 & 0.65 \\
lace2 & 2.591 & 1.778 & 1.47 & $0.14^{*}$ \\
lacm2 & -1.009 & 2.060 & -0.49 & 0.62 \\
Big4 & 14.056 & 5.600 & -2.51 & $0.07^{* *}$ \\
Ifsize & 93.843 & 39.413 & 2.38 & $0.02^{* *}$ \\
\hline
\end{tabular}

\section{CONCLUSIONS}

Based on the findings of this study, accounting/financial expertise as audit committee characteristic and audit quality impacts positively and significantly with financial instruments disclosure of listed Nigerian financial institutions. Hence, it is expected that financial instruments disclosure information will lead to more transparent financial 
reporting and enable contact to available financial information within financial institutions by regulators and other interested parties.

Although the proposed (e-FASS= Electronic and Financial Analysis Surveillance System) being envisaged by the newly established financial reporting council of Nigeria is beyond the scope of this study, effort should be intensified to facilitate on-line real-time rendition of monthly and annual returns to regulatory authorities using the innovation. This is possible with the collaborative effort of the financial reporting council of Nigeria (FRCN) and the institute of directors (IoD) of Nigeria. This study has shown that audit committee, big4 audit firm and firm size are important indicators of financial instruments disclosure and stability of financial institutions in Nigeria that regulators should lay more emphasis on.

This study, therefore, contributes to the growing demand for corporate governance literature on risk disclosure is twofold. Firstly, it contributes by its concentration or focuses on the risk related to the application of financial instruments which had been condemned in the financial crisis-era that stressed the turbulence of financial markets. Secondly, the contributions of this study offer valuable information to bank management, investors within the banking sector and the regulatory authorities in Nigeria by identifying the key governance attributes required to be supported or strengthened to attain huge financial transparency and gain the confidence of capital market operators through the reduction of information asymmetries.

\subsection{ReSEARCH BOUNDARIES AND SUggestions FOR FutURE StUdY}

This research uses a small sample size (50) as the population of the study. The study employs only financial data instead of non-financial or mixed financial and non-financial data. Short period of study and use of GMM as the only methodological analysis technique provide other limitations of this study. Future studies should take into account these important omissions.

\section{Reference:}

Abdul Rahman, R. \& Haneem M. A. F. (2006). Board, audit committee, culture and earnings management: Malaysian evidence. Managerial Auditing Journal, 21(7), 783-804.

Abiola, J. O. \& Ojo, S. O. (2012). Compliance with regulatory financial reporting and corporate governance practices in selected primary mortgage institutions in Nigeria. International Journal of Business and Social Science, 3 (15), 246-254.

Abor, J. (2007). Corporate governance and financing decisions of Ghanaian listed firms. Corporate Governance, 7(1), 83 - 92.

Abozaid, E. M., Elshaabany, M. M., \& Diab, A. A. (2020). The impact of audit quality on narrative disclosure: evidence from Egypt. Academy of Accounting and Financial Studies Journal, 24(1), 1-14. 
Ado, A. B., Rashid, N., Mustapha, U. A., \& Ademola, L. S. (2020). The impact of audit quality on the financial performance of listed companies Nigeria. Journal of Critical Reviews, 7(9), 37-42.

Albitar, K., Gerged, A. M., Kikhia, H. \& Hussainey, K. (2020). Auditing in times of social distancing: the effect of COVID-19 on auditing quality. International Journal of Accounting \& Information Management, 1834-7649, DOI 10.1108/IJAIM-08-20200128

Aledwan, B. A., Yaseen, A. A. B., \& Alkubisi, A. (2015). The Role of Audit Quality on the Relationship between Auditor's and Financial Performance Quality of Selected Cement Firm in Jordan. International Journal of Business and Social Science, 6(12), 138-146.

Allini, A., Ferri, L., Maffei, M., \& Zampella, A. (2020). Determinants of financial instruments risk disclosure: an empirical analysis in the banking sector. Corporate Ownership \& Control, 17(2), 20-31.

Andres, P., \& Vallelado, E. (2008). Corporate governance in banking: the role of the board of directors. Journal of Banking and Finance, 32, 2570-2580.

Andres, B.A., Smith, P.A., Morrison, G.I.Y., Cheri L. Gratto-Trevor, C.L., Brown, S.C. \& Christian A. Friis, C.A. (2012). An empirical evaluation of accounting income numbers. Journal of Accounting Research, 6 (2), 159-78

Arellano, M., \&Bover, O. (1995). Another look at the instrumental variables estimation of error components models. Journal of Econometrics, 68, 29-51.

Balagobei, S. (2018). Corporate governance and firm performance: empirical evidence from emerging market. Asian Economic and Financial Review, 8(12), 1415-1421, DOI:10.18488/journal.aefr.2018.812.1415.1421

Barako, D. G., Hancock, P. \& Izan, H. Y. (2006). Relationship between corporate governance attributes and voluntary disclosures in annual reports: the Kenyan experience. Financial Reporting, Regulation and Governance, 5(1), 1-25.

Bedard, J., Chtourou, S. M., \& Courteau, L. (2004). The effect of audit committee expertise, independence, and activity on aggressive earnings management. Auditing, 23(2), 13-36.

Berle, A. \& Means, G. (1932). The Modern Corporation and Private Property, Commerce Clearing House, New York, NY

Blundell, R. \& Bond, S. (1998). Initial conditions and moment restrictions in dynamic panel data models. Journal of Econometrics, 87, 115-143.

Bryan, D., Liu, M. H. C. \& Tiras, S. L. (2004). The influence of independent and effective audit committees on earnings quality. Working paper, Department of Accounting and Law, School of Management, State University of New York, Buffalo, NY.

Bryman, A. \& Cramer, D. (1997). Quantitative data analysis for social scientists, Rout ledge, London. 
Bryman, A., \& Cramer, D. (1997). Concepts and their measurement. Quantitative data analysis, with SPSS for Windows.

Bouaziz, Z. (2012). The impact of auditor size on financial performance of Tunisian companies. Faculty of Economics and Management. Sfax University, Tunisia.

Chersan, I-C, (2019), Audit quality and several of its determinants, Audit Financiar, vol. XVII, 1(153)/, 93-105, DOI: 10.20869/AUDITF/2019/153/002

Cooke, T. E. (1989). Disclosure in the corporate annual reports of Swedish companies. Accounting and Business Research, 19 (74), 113-124.

Cooke, T.E. (1992). The impact of size, stock market listing, and industry type on disclosure in the annual reports of Japanese listed corporations. Accounting \&Business Research, 22(87),229-37.

Curran, P. J., West, S. G., \& Finch, J. F. (1996). The robustness of test statistics to non-normality and specification error in confirmatory factor analysis. Psychological Methods, 1(1), 16-29.

Dahlquist, M., \& Robertsson, G. (2001). Direct foreign ownership, institutional investors, and firm characteristics. Journal of Financial Economics, 59, 413-440.

Daily, C.M., Dalton, D. R. \& Cannella, A.A. Jr (2003). Corporate governance: decades of dialogue and data. Academy of Management Review, 28 (3), 371-382.

Elewa, M. M., \& El-Hadded, R. (2019). The Effect of Audit Quality on Firm Performance: A Panel Data Approach. International Journal of Accounting and Financial Reporting, 9(1), 229-244.

Elshandidy, T., Shrives, P. J., Bamber, M., \& Abraham, S. (2018). Risk reporting: A review of the literature and implications for future research. Journal of Accounting Literature, 40, 54-82

Eshitemi, P. B., \& Omwenga, J. (2017). Effect of Audit Quality on the Financial Performance of Listed Parastatals In. Social Science and Humanities Journal, 144-157.

Falkenstein, E. (1996). Preferences for stock characteristics as revealed by mutual fund portfolio holdings. Journal of Finance 51(1), 111-135.

Farouk, M. A., \& Hassan, S. U. (2014). Impact of audit quality and financial performance of quoted cement firms in Nigeria. International Journal of Accounting and Taxation, 2(2), 1-22.

Favere-Marchesi, M. (2000). Audit Quality in ASEAN. International Journal of Accounting, 35(1), 121-149

Financial Reporting Council of Nigeria Act (FRCN, 2011). Federal republic of Nigeria official gazette, 54(98).

Gill, A. Biger, N., Mand H. S. \& Shah, C. (2012). Corporate governance and capital structure of small business service firms in India. International Journal of Economics and Finance, 4(8), 83-92. 
Glaum, M. \& Street, D. (2003). Compliance with the disclosure requirement of German's new market, IAS versus US GAAP. Journal of International Financial Management and Accounting, 14(1), 64-100. Doi:10.1111/1467-646X.00090.

Gompers, P., \& Metrick, A. (2001). Institutional Investors and Equity Prices. Quarterly Journal of Economics, 116, 229-259.

Hallak, I. (2013). Private sector share of external debt and financial stability: Evidence from bank loans. Journal of International Money and Finance, 32, 17-41. Doi:10.1016/j.jimonfin.2012.02.017

Haque, T. (1994). Is group affiliation profitable in emerging markets? An analysis of diversified Indian business groups. Journal of Finance, 55 (2), 867-891.

Hodgdon C., Tondkar, R. H., Harless, D. W. \& Adhikari, A. (2008). Compliance with IFRS disclosure requirements and individual analysts forecast errors. Journal of International Accounting, Auditing and Taxation 17, 1-13. Doi:10.1016/j.intaccaudtax.2008.01.002.

Hope, O. K., Hu, D., \& Lu, H. (2016). The benefits of specific risk-factor disclosures. Review of Accounting Studies, 21, 1005-1045

Hu, V. \& Jin, H. (2007). International financial reporting standards and Australian income tax. The Tax Specialist, 4 (3), 198-204.

Ibrahim, U. A. \& Danjuma, S. (2020). Effect of corporate governance on the performance of listed deposit money Banks in Nigeria. Science Journal of Business and Management 2020; 8(1): 35-40. Doi: 10.11648/j.sjbm.20200801.15

James, D. (1933). The Modern Corporation and private property, by Adolf A. Berle Jr. and Gardiner C. Means. Indiana Law Journal, 8(8), Article 11. Available at: http://www.repository.law.indiana.edu/ilj/vol8/iss8/11

Jensen M, \& Meckling, W. (1976). Theory of the firm managerial behavior, agency cost and ownership structure. Journal of Financial Economics.3: 305-360.

Jusoh, M. A., Ahmad, A., \& Omar, B. (2013). Managerial ownership, audit quality and firm performance in Malaysian. International Journal of Arts and Commerce, 2(10), 4558.

Kajananthan, R. (2012). Effect of corporate governance on capital structure: case of the Sri Lankan listed manufacturing companies. Researcher's world. Journal of Arts, Science and Commerce, 3(4), 63-71.

Karamanou, I. \& Vafeas, N. (2005). The association between corporate boards, audit committees, and management earnings forecasts: an empirical analysis. Journal of Accounting Research, 43 (3), 453-85.

Kao, L., \& Chen, A. (2004). The effects of board characteristics on earnings management. Corporate Ownership \& Control, 1(3), 96-107. 
Kline, R. B. (2011). Principles and Practice of Structural Equation Modelling (5th ed.). New York: The Guilford Press.

Lin, J.W., Li, J. F. \& Yang, J. S. (2006). The effect of audit committee performance on earnings quality. Managerial Auditing Journal, 21(6), 921-933.

Monametsi, G. L. \& Agasha, E. (2020). Audit quality and firm performance: Evidence from Botswana and Uganda. Journal of Accounting, Finance and Auditing Studies, 6(4), 79-95.

Monks, R. A. G., \& Minow, N. (2011). Corporate governance: Wiley

Mustafa, M. O. A., \& Muhammad, A. U. (2018). The nexus between audit quality and performance of listed oil and gas firms in Nigeria. International Journal of Innovative Research and Advanced Studies, 5(1), 222-231

Ogunsanwo, O. F. (2019). Effect of corporate governance on firm performance in Nigeria. OECONOMICA, AUDOE, 15(6), 82-97.

f-Ansah, S. (1998). The impact of corporate attributes on the extent of mandatory disclosure and reporting by listed companies in Zimbabwe. International Journal of Accounting, 33 (5), 605-631.

Owusu-Ansah, S., \& Yeoh, J. (2005). The effect of legislation on corporate disclosure practices. Abacus, 41 (1), 92-109.

Phan, T., Lai, L., Le, T., \& Tran, D. (2020). The impact of audit quality on performance of enterprises listed on Hanoi Stock Exchange. Management Science Letters, 10(1), 217-224.

Ruzaidah, R., \& Takiah, M. I. (2004). The effectiveness of audit committee in monitoring the quality of corporate governance. Corporate Governance: An International Perspective, Malaysian Institute of Corporate Governance, KualaLumpur, 154-75.

Saha, R., \& Kabra, K.C. (2019). Does corporate governance influence firm performance? Evidence from India. Economics and Business Review, 5 (19), 70-89 DOI: 10.18559/ebr.2019.4.4

Sattar, U., Javeed, S. A., \& Latief, R. (2020). How audit quality affects the firm performance with the moderating role of the product market competition: Empirical evidence from Pakistani manufacturing firms. Sustainability, 1- 20, 12, 4153; doi: $10.3390 /$ su12104153

Street, D., \& Bryant, S. (2000). Disclosure level and compliance with IASs: A comparison of companies with and without U.S. listings and filings. The International Journal of Accounting, 35(3), 305-329. Doi: S0020706300000601.

Street, D.L. \& Gray, S. J. (2002). Observance of international accounting standards: factors explaining non-compliance: Association of chartered certified accountants research report 74, and Retrieved October 1, 2013, from http://www.accaglobal.com 
Thai, K. H. P., \& Birt, J. (2019). Do risk disclosures relating to the use of financial instruments matter? Evidence from the Australian metals and mining sector. The International Journal of Accounting, 54(4), 1950017-1-1950017-36.

Vafeas, N. (1999). Board meeting frequency and firm performance. Journal of Financial Economics, 53, 113-142. Doi: 10.1016/s0304-405X (99)00018-5.

Vafeas, N. (2005). Audit committees, boards, and the quality of reported earnings. Contemporary accounting research, 22(4), 1093-1122.

Vijayakumaran, S., \& Vijayakumaran, R. (2019). Corporate governance and capital structure decisions: Evidence from Chinese listed companies. The Journal of Asian Finance, Economics $\quad$ Business 67-79. DOI:https://doi.org/10.13106/jafeb.2019.vol6.no3.67

Wakil, G. K., Alifiah, M. N., Teru, P. (2020). Auditor independence and audit quality in Nigeria public sector: a critical review. Journal of Critical Reviews, 7(7), 839-845.

Waresul Karim, A.K.M \& Ahmed, J.U. (2005). Determinants of IAS disclosure compliance in emerging economies: Evidence from exchange listed companies in Bangladesh. WorkingPaper Series Working Paper no. 2.

West, S. G., Finch, J. F., \& Curran, P. J. (1995). Structural equation models with non-normal variables: Problems and remedies. In R. H. Hoyle (Ed.), Structural equation modelling: Concept, issues, and applications (pp. 56-75). Thousand Oaks, CA: Sage Publication, Inc.

Xie, B., Davidson, W. N., \& DaDalt, P. J. (2003). Earnings management and corporate governance: the role of the board and the audit committee. Journal of Corporate Finance, 9(3), 295-316. Doi: 10.1016/S0929-1199(02)00006-8.

Yu, F. (2008). Analyst coverage and earnings management. Journal of Financial Economics, 88, 245-71.

Zaid, M. A. A., Wang, M., Sara T. F., Issa, A. A., Saleh, M. W.A. \& Ali, F. (2020). Corporate governance practices and capital structure decisions: the moderating effect of gender diversity, 20 (5), 939-964, DOI 10.1108/CG-11-2019-0343.

Zhang, Y., Zhou, J. \& Zhou, N. (2007). Audit committee quality, auditor independence and internal control weaknesses. Journal of Accounting and Public Policy, 26, 300327. 